\title{
Schelling's substantive reinterpretation of the transcendental turn: beyond method
}

\author{
Sebastian Gardner
}

\begin{abstract}
.
Several factors, including but not limited to his investments in Naturphilosophie and Spinoza, make it hard to determine the extent to which Schelling remains on track with Kant's transcendental project. My aim here is to isolate Schelling's conception of transcendental method in the first decade of his philosophical development, a topic that has received little direct and extended discussion. Schelling's 1800 System of Transcendental Idealism stands out as of particular importance, but no single text can be regarded as Schelling's definitive statement of his views on the question of method in his early period, necessitating a diachronic approach. I argue that, though in important respects Schelling's concerns diverge from those of Kant and Fichte, Schelling should not be regarded as abandoning the transcendental framework, and is best understood as attempting to work out what is involved at the original point of adoption of the transcendental standpoint. This entails, I argue, exchanging transcendental philosophy's claim to a distinctive method for a substantive interpretation of the transcendental turn.
\end{abstract}

\section{Where does Schelling stand?}

With regard to any philosopher who takes their initial bearings from Kant, it can be asked whether they remain within the frame of Kant's own transcendentalism, or modify it, or abandon it altogether. The answer will depend of course on our general criterion for commitment to the transcendental method in philosophical reflection, ${ }^{1}$ and here it will be agreed that heavy borrowing from Kant's conceptual stock is not sufficient: concepts such as apperception, synthesis, a priori conditions of knowledge, and distinctions such as those between intuition and concept, or understanding and reason, are developed by Kant in the course of an analysis which aims at transcendental proof, ${ }^{2}$ but they are not necessarily tied to this original methodological setting, and much later nineteenth- and twentieth-century philosophy shows how they can be reemployed independently. Nor, for the same reason, can transcendentalism be identified simply with attunement to the 'metacritical' issue raised by Kant's endeavour, of making intelligible what the business of metaphysics consists in: the question of what is being said or meant, and on what basis, when metaphysical claims

\footnotetext{
${ }^{1}$ For helpful discussion, see Tom Rockmore and Daniel Breazeale (eds), Fichte and Transcendental Philosophy (Basingstoke: Palgrave Macmillan, 2014), Pt. I.

${ }^{2}$ As defined in the Critique of Pure Reason at A782-94/B810-22.
} 
are made, is undoubtedly central to post-Kantian philosophy, ${ }^{3}$ but pursuing it does not entail commitment to a specifically transcendental mode of answering it.

A narrower and familiar criterion for transcendental methodology is that it consists in the strategy of addressing de jure questions on the supposition that these have no plain and direct answers of a sort derivable from classical empiricism or early modern rationalism, where this is taken to entail seeking a source of justification for claims to knowledge within the subject conceived in some non-empirical respect. Implied by this conception of transcendental subjectivity is some form of transcendental idealism.

If accepting this approach as the correct starting point for philosophical reflection is the criterion for commitment to transcendental methodology, then there can be no doubt that Schelling counts as a transcendental thinker. But everything hangs on what is implied by its acceptance as a starting point. How far is it possible to travel away from it, before it dwindles to irrelevance? For example, if continuing to uphold Kant's subjectivism is necessary for transcendentalism, then again we reach a quick (and the very opposite) result: Schelling's philosophy is not transcendental.

An alternative criterion, which gives purpose to enquiry into Schelling's relation to transcendentalism, would require holding fast, after the inadequacy of classical empiricism and rationalism has been recognized, to the notion that the correct method of metaphysics must derive from necessities of thought that have no prior or external anchoring, in other words, to maintaining the self-sufficiency of philosophical reflection and repudiating any appeal to independent, 'merely given' resources. ${ }^{4}$ On such a conception, transcendental reflection is originally free of ontological commitment in the sense that it is not itself originally beholden to any claim to knowledge of the existence of any entity, but instead takes such claims as its object; ${ }^{5}$ whence the notion that transcendental philosophy is essentially methodological, that is, defined by a procedure of reflection or mode of apprehension in thought, the necessity of such austerity being the great lesson drawn by Kant from the history of early modern philosophy.

\footnotetext{
${ }^{3}$ See A. W. Moore, The Evolution of Modern Metaphysics: Making Sense of Things (Cambridge: CUP, 2012).

${ }^{4}$ See Walter Schutz, 'Das Problem der absoluten Reflexion', in Vernunft und Freiheit, 6-38 (Stuttgart: Reclam, 1981).

${ }^{5}$ See Mark Sacks, Objectivity and Insight (Oxford: OUP, 2003).
} 
In this more demanding sense it is possible to regard Schelling as a transcendental thinker only for a relatively brief period and in a somewhat superficial regard. On such a view, Schelling may begin officially as a Fichtean, committed to deriving all things, theoretical and practical, from the absolute Ich, but he quickly discovers himself to be dissatisfied by the transcendental approach, and a major part of his philosophical practice, shortly after if not quite at the beginning of his philosophical career, involves translating Kant's transcendentally reconstructed versions of traditional metaphysical notions back into their original, pre-transcendental forms; whence, compared to Fichte, his receptiveness to Spinoza and Leibniz. Schelling thus makes ample use of the conceptual stock bequeathed by Kant - indeed by dint of the close attention that he pays to the Third Critique, he ends up employing a greater quantity of it than Fichte - but not in a way that is constrained by commitment to transcendental methodology. On this account Schelling does not belong to the crucial sequence in which the principal moments are Kant, Fichte, and Hegel, all of whom are fundamentally concerned, in a way that Schelling is not, with maintaining the autonomy of philosophical reflection, and his role is restricted to furnishing schemas that prove useful to Hegel in his attempt to get beyond Fichte's (still problematic) revision of Kant's (problematic) transcendentalism, ${ }^{6}$ while his own philosophical contribution, whatever it may amount to, does not include a self-standing account of what it means for philosophy to adopt the (or a) transcendental method.

This assessment may seem supported by Schelling's development of a large-scale philosophy of nature, and his own (eventual) explicit declaration of the philosophical inadequacy of Fichte's Wissenschaftslehre, along with the appeal that he makes at one point to art as offering privileged philosophical insight, and his philosophical elevation of mythology and revealed religion in his final decades. It also coheres with Hegel's wellknown criticism of Schelling as failing to engage responsibly with the question of the epistemology of the absolute and allowing his system to rest on a merely dogmatic foundation, and with Fichte's parallel charge, from 1800 onwards, that Schelling betrays a failure to grasp the meaning of transcendental idealism. ${ }^{7}$

\footnotetext{
${ }^{6}$ In what sense if any Hegel may be counted a transcendental thinker is disputed but not presently at issue: Hegel's claim for the comprehensiveness and exhaustiveness of his Logic suffices to draw the relevant contrast with Schelling.

${ }^{7}$ See Fichte's letters to Schelling of 15 November 1800, 31 May-7[8?] August 1801, and 8 October 1801, in Michael G. Vater and David W. Wood (eds.), The Philosophical Rupture
} 
My aim in this paper is to explain why, although there are, as just indicated, several reasons why one may be led to picture Schelling as only a part-time and short-term fellow traveller in the development of transcendentalism, this characterization is essentially incorrect. To state my conclusion in advance, what matters come down to, I will argue, is that Schelling uncovers a constellation of commitments within the original transcendental starting point, regarded by Kant as off-limits and not registered by Fichte or Hegel. Though Schelling's redirection of Kantianism, viewed from one angle, involves the intrusion of an alien realist tangent into the idealist framework, leading him off the transcendental path, from another perspective, which I hope to make plausible, his achievement may be held to lie in his having disclosed how much more - of a problematic nature - is contained in the original adoption of the transcendental stance than Fichte and Hegel recognize or are able to accommodate. On this view, Schelling shows the possibility of an alternative construal of Kant's transcendental turn which is substantive rather than methodological, and which qualifies (though without altogether relinquishing) its claim to autonomy. Whether Schelling's alternative is superior to Fichte and Hegel is not a matter to be settled here, where my aim is restricted to explicating Schelling's view and the motivation he adduces for it. The next three sections examine accordingly the major points at which Schelling engages with questions of transcendental method in the first wave of his philosophical development. ${ }^{8}$ On this textual basis I offer in the final section a view of how Schelling understands the transcendental turn.

\section{The platonistic transcendentalism of Schelling's Formschrift and Ichschrift}

between Fichte and Schelling: Selected Texts and Correspondence (1800-1802) (Albany, NY: SUNY, 2012), 41-3, 54-9, 66-8.

${ }^{8}$ For more detailed discussion, see Frederick Beiser, German Idealism (Cambridge MA: Harvard University Press, 2002), Pt. IV, Joseph Esposito, Schelling's Idealism and Philosophy of Nature (Lewisburg: Bucknell, 1977), Dalia Nassar, The Romantic Absolute (Chicago: University of Chicago, 2014), Pt. III, and Birgit Sandkaulen-Bock, Ausgang vom Unbedingten (Göttingen: Vandenhoeck \& Ruprecht, 1990). 
Schelling's earliest published works, the so-called Formschrift (1794) and Ichschrift (1795), ${ }^{9}$ situate themselves squarely in the context of Kant's philosophical results, to that extent, it may be supposed, implying endorsement of the method Kant employs to reach them. Matters are, however, not so clear. ${ }^{10}$ The Formschrift levels a number of criticisms converging on the conclusion, familiar from early Kant reception, concerning Kantianism's need for a single principle, though on a different basis from Reinhold, Fichte, and others. Namely: (1) Kant presupposed an original (systematic) 'form of all philosophy' (Urform), which he nowhere articulates in the form of a principle. (2) Kant consequently lacks what we do find (albeit inadequately formulated) in Leibniz, namely as the axioms (Grundsätze) of the Principle of Non-Contradiction and the PSR. (3) Kant's analytic/synthetic distinction serves proxy for those axioms (and even to some extent improves their formulation), but this distinction is asserted by him without explanation or derivation. (4) Kant's lack of a superior principle is reflected in the unsatisfactory character of his table of the categories, which are not clearly differentiated from one another. In the Ichschrift Schelling restates these points with some differences of formulation, and lengthens the charge sheet: (5) Space and time are taken as given by Kant without consideration of a principle from which they might derive. (6) All of the syntheses posited by Kant in the categories and judgements, including the all-enveloping 'synthesis of multiplicity in the unity of consciousness as such', remain unintelligible unless they are understood 'through a superior absolute unity', unacknowledged by Kant. (7) Kant offers no principle for the connection of theoretical with practical philosophy, with the result that they do not 'appear to be oneand-the-same structure'. ${ }^{11}$

${ }^{9}$ Über die Möglichkeit einer Form der Philosophie überhaupt and Vom Ich als Princip der Philosophie oder über das Unbedingte im menschlichen Wissen, transl. On the Possibility of a Form of All Philosophy and Of the I as Principle of Philosophy, or On the Unconditional in Human Knowledge, in The Unconditional in Human Knowledge: Four Early Essays 1794-1796, ed. Fritz Marti (Lewisburg: Bucknell University Press, 1980). References to Schelling are first to pagination of the translation, from which quotations are taken, and then in square brackets to volume and page number of his Sämmtliche Werke, 14 vols., ed. Karl Friedrich August Schelling (Stuttgart: Cotta, 1856-61).

${ }^{10}$ See Schelling's letter to Hegel, 6 January 1795, Aus Schellings Leben. In Briefen. Band 1: 1775-1803 (Leipzig: Hirzel, 1870), 73.

${ }^{11}$ Ichschrift, 65-6 [I 153-4]. 
The remedy is supplied, Schelling asserts, by taking as the highest Grundsatz 'A=A' or 'I=I'. The Formschrift provides brief supporting argument for this Fichtean claim, ${ }^{12}$ later elaborated in the Ichschrift, but for immediate purposes, the important point concerns the level at which Schelling is arguing. As just seen, Schelling presses hard for systematic completeness. Is this a transcendental requirement? Knowledge of that which ultimately determines our forms of thinking does not in any obvious or straightforward sense help to explain, or add to our capacity to justify, the claims of ordinary Erfahrung. The case can be made however, and is made by Fichte, that it qualifies nonetheless as an indirect transcendental requisite, by virtue of being required in order to tie up the several loose ends left by Kant, and, connectedly, in order to deflect radical skeptical attacks on Kantianism such as those of Schulze and Maimon. ${ }^{13}$ What is clear at any rate is that, if systematic completeness demands that all conceptualization derive from an unconditionally necessary ergo unitary source, then the standard Kantian transcendental rubric - viz., identifying the conditions of possible experience and thereby furnishing transcendental proof of the relevant object-constituting principles - fails to encapsulate the task of philosophy, which needs to develop, if not instead then in addition, top-down, and to no longer allow its boundaries to be set by the experiential interface of the knowing subject with given objects of cognition.

The need for such an approach is of course affirmed in Fichte's Grundlage der gesammten Wissenschaftslehre of 1794/5. What differentiates Schelling's approach from the Wissenschaftslehre is Schelling's direct concentration in the Formschrift on the distinction between form and content in his attempt to establish 'the possibility of philosophy'. In summary, Schelling's argument is that, if philosophy is to be possible as a system, then the principle that makes it possible must be considered to have form and content, and to have two aspects: outwardly it must be such as to condition all other Wissenschaft, whilst inwardly it must itself derive from an unconditioned source. The difficulty lies in understanding the latter, and here Schelling's texts exhibit complexity, and reveal strain, in a way that will prove of enduring importance for his philosophical development.

Unconditionality requires that neither form nor content have precedence over the other, from which it follows that they must yield one another reciprocally. As Schelling

\footnotetext{
${ }^{12}$ Formschrift, 45 [I 96-7].

${ }^{13}$ See Formschrift, 38-9 [I 88-9].
} 
puts it, 'such a proposition' - the sought-for highest principle - 'can be given only by its own criteria [nur durch seine eigenen Merkmale gegeben seyn]'. ${ }^{14}$ But in thinking of form and content as standing in the relation of reciprocal determination, we seem to be assigning each term an identity of its own (since any criterion must be distinguishable from what is measured by it). The conclusion towards which Schelling initially appeared to be headed when he asserted the inner unconditionality of the source of philosophical cognition, is that the very distinction of form and content vanishes in a supreme principle which is strictly supra-relational, ${ }^{15}$ but to draw it would, obviously, undermine its status as a principle. Accordingly Schelling maintains the distinctness (at least conceptual or rational) of form and content, while conceding that their reciprocal determination forms a 'magic circle' and intimating that its articulation as a principle involves a compromise with discursive necessity. ${ }^{16}$

The distinctiveness of the Formschrift in confirmed by comparison with the equivalent text in Fichte's corpus, Über den Begriff der Wissenschaftslehre, published slightly earlier in 1794. Fichte too makes the case for the necessity of a single principle in which form and content are necessarily connected, and the content of which contains systematic form, ${ }^{17}$ but what drives his argument is simply the familiar Cartesian foundationalist necessity that we show how certainty is possible. ${ }^{18}$ Fichte consequently, and consistently with this aim, defines systematic form in a way that reduces it to the mere inferential transmission of certainty. ${ }^{19}$ Schelling too, of course, thinks that the supreme principle of philosophy must be doubt-proof and transmit its indubitability to whatever is derived from it, but the production of certainty is not the condition to which the system of philosophy, according to the Formschrift, is ultimately answerable: epistemic properties

\footnotetext{
${ }^{14}$ Formschrift, 44 [I 96-7].

${ }^{15}$ One might consider this implied by what is said in the Formschrift, 43, 44 [I 94, 96].

${ }^{16}$ Formschrift, 43 [I 94]. The problem resurfaces in STI, 19-21 [III 358-60].

17 'Concerning the Concept of the Wissenschaftslehre' [CCWL] (1794), in Early
}

Philosophical Writings, trans. and ed. Daniel Breazeale (Ithaca: Cornell University Press, 1988), 109-10.

${ }^{18}$ The principle must be 'certain in itself, through itself, and for its own sake' (CCWL, 108). See also $C C W L, 102$ - the touchstone is something which the subject 'really does know and can know' - and the Second Preface (1798), 97.

${ }^{19}$ CCWL, 104-5. 
are regarded by Schelling as markers and consequences of philosophical insight, ${ }^{20}$ but they do not encompass its final objective. This concern of Schelling's with knowledge of form on its own account, not merely for the sake of the epistemology of worldly claims to knowledge, may fairly be described as platonistic.

A further relevant difference from Fichte may be noted. Fichte states in the Preface to Über den Begriff that what he is about to describe is 'hypothetical': it represents the only possible foundation of knowledge, if there is knowledge, i.e., if there is some actual relation of some content to the consciousness of a person said to 'know' it. ${ }^{21}$ The principle targeted in Schelling's Formschrift rests on no such condition: the unconditioned is already ('absolutely') known, prior to any epistemic conditionals. In some sense, therefore, it antedates 'possible experience', for which (along with everything else) it is of course necessary, but not merely qua condition of it or in relation to it.

That Schelling does not share Fichte's conception of the source of unconditionality, and so must employ other means, becomes clear when he expands his identification of the absolute with Ichheit in the Ichschrift. His argument here mirrors neither Kant's extrapolation of the transcendental unity of apperception from the necessity of the representation-bound 'I think', nor Fichte's claim that postulation of the absolute I is necessitated from the interior of self-consciousness, nor Fichte's argument that it is demanded as a condition for the possibility of certainty. What Schelling envisages is a form of absolute reflexivity which he wants to connect inseparably, but declines to identify outright, with either the epistemic reflexivity of self-validation or the self-given reflexivity of self-consciousness. It is instead intended to precede both. For this reason, in his attempt to positively explicate absolute Ichheit, Schelling moves directly to talk of freedom and causa sui.

So far, then, we have seen how certain philosophical motives in Schelling's earliest writings do not replicate lines of thought in Kant and Fichte, but no conflict as such has emerged: in so far as the Formschrift and Ichschrift subscribe to the aim of deriving the reality of cognition from a single principle interior to philosophical reflection, they participate in the transcendental project, despite the difference of Schelling's way of showing the self to be the supreme principle of knowledge from those of Kant and Fichte.

\footnotetext{
20 The 'magic circle' is what grounds the 'absolute evidence' of the highest Grundsatz, hence is strictly distinct from it (Formschrift, 43, 45 [I 94, 97]).

${ }^{21}$ CCWL, 95 and 102.
} 


\section{Schelling's 1800 System of Transcendental Idealism: revision of the transcendental method in the light of Naturphilosophie}

Later in the 1790s Schelling publishes the series of texts that constitute his Naturphilosophie, and up until 1800, his readers might have been forgiven for wondering how, and indeed whether, the two lines of thought that he has been pursuing are supposed to join up. Schelling's investigation of Nature - though perhaps not strictly inconsistent with Fichte's Wissenschaftslehre, if one downplays some of Schelling's stronger assertions concerning the status of Naturphilosophie - does not appear to belong to the same movement of thought as that which proclaims the reality of the absolute Ich and the absolute primacy of freedom. It is not until the System of Transcendental Idealism (STI) that Schelling addresses directly the question of what, on his view, the transcendental method amounts to.

The account that emerges in the opening sections of STI is complex and original. What Fichte has furnished, Schelling declares, is only the 'elementary principles' of a subcomponent of one half of the total system of philosophy. Specifically, the Wissenschaftslehre contains a theory of the (merely) ideal component of what Schelling himself conceives as transcendental philosophy. What this means becomes clearer when the full system has been presented, which in turn involves grasping the way in which Schelling came to conceive it, a process in which his Naturphilosophie is revealed to have played a key role.

A direct interest in understanding nature on its own account, in a way that is thematically continuous with the physics of Kant's Metaphysische Anfangsgründe and the theory of organic nature in the Third Critique, but which is not motivated strictly and exclusively by transcendental requirements, and which instead recalls Goethe's endeavour to penetrate to the inner source of Nature in itself, ${ }^{22}$ led Schelling, beginning in 1797, not simply to reflect on extant natural science in the regressive Kantian spirit of asking what its a priori presuppositions might be, but to attempt, in Goethean manner, to creatively extend the theory of nature in original philosophical terms. These terms were heavily indebted to Fichte, whose theory of the Ich provided Schelling with his key ideas about how to model

\footnotetext{
${ }^{22}$ Goethe's Versuch die Metamorphose der Pflanzen zu erklären, with its theory of the Urpflanze, was published in 1790.
} 
Nature philosophically, yet the Naturphilosophie that resulted was not a piece of Fichteanism: on the contrary, Schelling's interest in Nature as an immediate self-standing philosophical explanandum violated the Fichtean stricture that no reality should be granted Nature that has not been derived in advance from the principles of the Wissenschaftslehre; for Fichte, Nature as such cannot call for explanation, since this will necessarily have already been supplied by the derivation which licensed our original positing of it.

The situation, as Schelling explains it in STI, is that we now find ourselves, thanks to Naturphilosophie, in possession of the new knowledge, not owed to Fichtean procedures, that Nature has the structure of Intelligenz (Schelling's preferred term in this text for rational subjectivity ${ }^{23}$ ). This prompts the two major innovations that differentiate Schelling's position in STI from Fichte's Wissenschaftslehre, and which by Fichte's lights compromise the autonomy of transcendental reflection.

First, Schelling claims that we have been brought to see that Naturphilosophie constitutes one independent, irreducible part of philosophy. ${ }^{24}$ It is independent because, although the way that Schelling theorizes Nature certainly took its cue from Fichte, this relation is ultimately contingent: enlightened philosophical reflection would, Schelling supposes, have led to the same conclusions regarding Nature's essence. And what shows that, initial appearances to the contrary, this elevation of Nature poses no (Spinozistic) threat to transcendentalism - and hence need not be countered in the way that Fichte opposes his idealism to dogmatism - is precisely the fact that the structure which has been discovered in Nature is the same as that of Intelligence. The conclusion to be drawn accordingly, Schelling argues, is that Naturphilosophie stands in parallel with the type of idealism initiated by Kant and developed to a higher level by Fichte.

Second, and of particular importance for the topic at hand, what we have been brought to see is that there is an alternative way of completing the other, transcendental part of philosophy, which differs from the Wissenschaftslehre and leads to the devaluation and circumscription of Fichte's achievement described above. Taking as our starting point the same fundamental question as that with which Kant's Critique of Pure Reason and Fichte's Grundlage begin - namely: How in general is cognition originally possible? Schelling argues that the transcendental philosopher may, and should, attempt to answer it,

\footnotetext{
${ }^{23}$ STI, 5 [III 339].

${ }^{24}$ STI, 6 [III 340-1].
} 
not exclusively by reflection on the subjective conditions which must be in place for cognition to result, but in addition by reflection on the constitution of its real object. ${ }^{25}$

Thus, just as the total system of philosophy envisaged by Schelling has two parts, one of which begins on the subjective or 'ideal' side (transcendental philosophy) and the other on the objective or 'real' (Naturphilosophie), so too does the former part divide into two aspects: cognition should be understood, within transcendental philosophy, as involving the congruence of (i) the constitution of real objects, with (ii) that of the subjective representations we form of them; that is, as a matter of co-determination of object and act of cognition. The concrete meaning of this proposal emerges in due course in STI, when we see how Schelling's deductions actually work, ${ }^{26}$ but the basic thought is sufficiently clear. When Kant in the Preface states his Copernican hypothesis that our mode of cognition is determinative of the objects of cognition, he opposes it to another (viz., the hitherto universally accepted) conception in which the direction of determination is reversed, but he does not pause to consider the possibility that the relation might be one of necessary reciprocal determination. Kant excludes this or any other third possibility, and this is because the only form which he envisages it as capable of taking is that of the (hopeless) Leibnizian theory of pre-established harmony. ${ }^{27}$

Schelling by contrast makes free use of the concept of pre-established harmony (vorherbestimmte Harmonie) to denote his way of thinking. However, Leibniz's version of the doctrine is not what is being proposed in STI. A harmony of constitutions which is preestablished, sensu stricto and on Leibniz's conception, is one that has been engineered antecedently by some entity independent of both the cognizing subject and the cognizing object. This is what gives the agreement of representation and object the appearance of a fortuitous accident, and renders the hypothesis vulnerable to skepticism in all the ways that Kant is anxious to avoid. What Schelling envisages, by contrast, is a harmony established

\footnotetext{
${ }^{25}$ Described as a 'history of self-consciousness', composed of a 'graduated sequence of intuitions' (STI, 2 [III 331]).

${ }^{26}$ STI, 60-72 [III 411-26] shows how Schelling's transcendental method departs from Fichte: productive intuition, Produciren or produktiven Anschauung, replaces Fichtean Setzen, and what is produced is the thing in itself, yielding 'two opposites really opposed to each other' as the two factors in intuition.

${ }^{27}$ Critique of Pure Reason, B166-8, concerning the idea of a Präformationssystem of pure reason.
} 
within the compound 'subject-cognizing-object', i.e., one which by virtue of its internality avoids all appeal to external anchoring, in a way that would disqualify Schelling's claim to have proposed a new yet genuinely transcendental methodology. The formula employed to express this point is that of identity of subject and object. ${ }^{28}$

Now it is evident that, even if Schelling's claim to be innovating the transcendental method is formally admissible, two urgent questions are now on the table. One: If the system of philosophy has two parts, how are these (known to be) joined? Mere talk of parallelism seems descriptive rather than explanatory. Two: If the transcendental part of the system of philosophy, in its revised, Schellingian form, appeals to a 'subject-cognitionobject' totality, what is the nature of this whole, and what epistemic assurance do we have of its reality?

The answer to the second question - which will lead us indirectly to Schelling's answer to the first - emerges when we take note of the specific twist that Schelling employs in explaining how he conceives his transcendental method. The problem with the type of proofs that Fichte offers in the Wissenschaftslehre, Schelling says, is that they are merely teleological, hence fail to establish anything more than requirements of ideality. ${ }^{29}$ In other words, they tell us how objects of cognition need to be thought to be - more precisely: how objects need to be thought to be represented in experience, or thought to be experienced as being - but they do nothing to show that this need is actually fulfilled. ${ }^{30}$ What (alone) would satisfy this condition is a deduction that exhibits the mechanism of cognition, or, as Schelling also puts it, that displays its 'real origin'. ${ }^{31}$

Now it is clear, even without the independent evidence supplied by Schelling's intensive discussion of the problem of the relation of mechanism and teleology in his earlier naturphilosophisch texts, that when Schelling talks of a necessary complementarity

${ }^{28}$ STI, 11-12 [III 348-9].

${ }^{29}$ STI, 3-4 [III 332-3].

${ }^{30}$ Schelling is, note, locating the same fault in Fichte as Kant locates in the Präformationssystem (and, incidentally, that Maimon located in Kant): namely that it leaves me only 'able to say that', due to my subjective organization, 'I am so constituted that I cannot think this representation otherwise'; which is 'what the sceptic most desires' (B168).

${ }^{31}$ Which Schelling calls 'eine wirkliche [Akt der] Construktion der Objekte': STI, 3, 13 [III $333,350]$. 
of 'mechanistic' and 'teleological' determination within cognition, what he has in mind is the solution to the dialectic of teleological judgement in Kant's Third Critique. This consists, briefly stated, in the positing of a supersensible ground of unity of the teleological and mechanistic orders that we judge to be found in nature. Correlated with this postulation is Kant's theory of the intuitive intellect, for this, on Kant's account, is required in order to explain how there can be, or how our mode of cognition can be such as to come to represent there being, two such structurally different orders, which are nevertheless fundamentally in accord with one another, that is, both externally in nature as a realm of appearance, and co-thinkable by the human intellect. Kant of course intends his positing of a unifying supersensible ground of mechanism and teleology, and the intuitive intellect, in terms much epistemically weaker than those that Schelling requires for his transcendental account of cognition in STI: Schelling must suppose to be constitutive what Kant regards as 'merely regulative'. But the key point stands nonetheless: If Kant is right that reflection on the conditions of possibility of certain objects, those that we call living organisms ('natural ends'), commits us to this postulation, then it cannot be objected to Schelling that his use of the same idea in explaining cognition in general breaks with the constraints imposed by the transcendental method. What can be said, of course, is that Schelling has disregarded or overridden Kant's distinction of the constitutive and the regulative. But that is strictly another matter, about which Schelling has much to say elsewhere: his case for Naturphilosophie involves an extended critique of Kant's tactic of regulativity as a means to epistemological modesty. ${ }^{32}$

The other tabled question still requires an answer. Supposing Schelling to have a rightful claim to modify transcendental method in the way described, how is the system of philosophy which employs this method related to his Naturphilosophie? The question is of importance if only because, in the absence of a unitary perspective encompassing both

\footnotetext{
${ }^{32}$ In briefest summary: regulativity may define the status of certain principles in accordance with which scientific research should proceed, but it cannot coherently pertain to the philosophical theory of nature, for to approach Nature 'as if $X^{\prime}$ just is to affirm Nature's intrinsic constitutional $X$-warrantingness; which it is the job of metaphysics to explicate. See Schelling's Ideen zu einer Philosophie der Natur (1797, 2nd expanded edn. 1803), II 187-200 and 291-5. For further discussion see my 'German Idealism, Classical Pragmatism, and Kant's Third Critique', in Pragmatism, Kant, and Transcendental
} Philosophy, ed. Gabriele Gava and Robert Stern (London: Routledge, 2016), 22-45. 
systems, or system-parts, it may reasonably be objected that there is no need, perhaps even no scope, for the same job to be done twice. If either story-version suffices in its own terms, what need is there for the other? More pointedly: If Naturphilosophie recounts the story with reference to objects qua real, then why not regard Schellingian transcendental philosophy as a mere heuristic, perhaps of use in showing us how to escape the methodological solipsism which has conditioned philosophical reflection since Descartes, but which has no further, positive philosophical value of its own?

Schelling's intention in STI is certainly not to reduce transcendental philosophy to a mere negative epistemological propaedeutic to the true metaphysical story, and if the conception of transcendental method which he develops there is correct, then we can see why Naturphilosophie cannot be granted monopoly rights: if transcendental reflection on the objects of cognition reveals them to be double-aspected, i.e., identities of the real and the ideal, then explication of what makes them susceptible to cognition leads to conclusions which have full metaphysical reality. The same result is supported by Naturphilosophie in so far as it discovers light, gravity, etc., to be resolvable into activity. (So as Schelling puts it: the two system-parts 'mutually presuppose and demand' and 'must seek each other'. ${ }^{33}$ )

That Schelling takes the model of equally weighted double vision seriously becomes clear when we see how he pursues its implications. ${ }^{34}$ The integrity and credibility of the whole turns on our assurance of the harmony of its system-parts, and since this harmony cannot be discovered outside them, it must be furnished from within each, that is, presented in a twofold manner. And this is achieved, Schelling argues, by the teleological portion of Naturphilosophie, and by the role of philosophy of art in transcendental thinking: organic life and artworks show the identity of the system-parts, in their respectively and complementarily unconscious and (self-)conscious forms, in so far as they exhibit the identity of the ideal and the real überhaupt.

\section{Schelling's Identity Philosophy: transcendentalism fused with Spinozism}

\footnotetext{
${ }^{33}$ STI, 6, 7 [III 340, 342].

${ }^{34}$ STI, 11-12 [III 347-9].
} 
The Formschrift and Ichschrift, we saw, locate themselves within the development of transcendental philosophy, while demanding a single principle to remedy Kant's defects. The STI, however, denies that any such principle is possible. How is this to be understood?

That more is involved in STI than simply releasing transcendental philosophy from the stringent single principle requirement and incorporating it within a larger philosophical structure, can be seen if we go back to the difficulty encountered in the Formschrift noted earlier. Schelling's claim there was that transcendental philosophy forces recognition of the unconditioned absolute: this result is delivered immediately, Schelling claimed, by Kant's new philosophical method. What has been asserted in STI is that this unconditioned absolute, though made manifest by transcendental reflection, cannot be grasped by it. Nor, moreover, can it be grasped through the conjunction of transcendental philosophy and Naturphilosophie. The text makes it quite clear that Schelling intends no such claim: the final object of philosophy, as described in STI, is the identity of Intelligenz and Nature, yet, Schelling writes, 'in so far as I wish to explain this identity, I must already have done away with it', for the straightforward reason that explanation, in whichever direction it goes, entails giving priority to the one factor over the other, cancelling the identity. ${ }^{35}$ What can be done instead is (only) to account for their (mere) coincidence (Uebereinstimmung, Zusammentreffen) in cognition. ${ }^{36}$ This explanatory task, we have seen, can be discharged in two ways, and when these are fitted together, we can claim to have secured through their conjunction 'the supreme principle for all knowledge', and to that extent to have solved the 'main problem' (Hauptaufgabe) of philosophy qua science. ${ }^{37}$ But the unconditioned absolute itself is not captured in the systematic net. It remains outside it. This is again made clear when Schelling emphasizes, in Part One of STI, that the highest principle sought in transcendental philosophy is a principle of knowledge but not a principle of being, and that self-consciousness 'is not a kind of being for us, but a kind of knowing'; 38 and that the very same is true of Naturphilosophie, since it resolves Nature into (so to speak) unconscious self-consciousness. ${ }^{39}$

\footnotetext{
${ }^{35}$ STI, 5 [III 339].

${ }^{36}$ STI, 3, 6, 7 [III 339, 342].

${ }^{37}$ STI, 7 [III 342].

${ }^{38}$ STI, 16 [III 354].

${ }^{39}$ STI, 17 [III 356].
} 
Now it may be observed that Schelling's system in 1800 appears to bear the same type of relation to the unconditioned absolute as Kant's system does to the thing in itself, ${ }^{40}$ and this prompts the question of what, if anything, has been gained by Schelling's overhaul of Kant's transcendental idealism. The answer is, everything and nothing: the latter, to the extent that it remains true for Schelling too that the unconditioned, though obliquely yet immediately present to thought in some sense, is not a possible object of cognition; and the former, to the extent that the boundaries of philosophical comprehension have been pushed all the way back, tying up Kant's loose ends and leaving cognition fully self-transparent. Schelling's claim is therefore to have rendered Kant's 'land of truth' borderless: it remains conditioned in its unbounded wholeness, but its conditioning by the unconditioned has been comprehended in the exact sense denied by Kant.

One way of viewing the point Schelling has reached in STI, which underlines his difference from Fichte as well as from Kant, is in terms of the Kant-Spinoza opposition, regarded by Fichte, but not by Schelling, as a relation of contradiction. Spinoza's importance for Schelling philosophy is of course reflected in his Naturphilosophie, but only in a relatively limited sense, since, as just seen, Naturphilosophie lies for Schelling on the same conceptual plain as transcendental philosophy (it comprises the full kantianization of Nature). Schelling's truly Spinozistic dimension reveals itself outside both his transcendental and his Naturphilosophie. It shows up early on in Schelling's recasting of the ontological argument in the Ichschrift - the argument fails, he says, in so far as it proceeds from a conception of God-as-object, yet it correctly expresses what is involved for God himself in his own thinking of his own $I c h^{41}-$ and it is present in STI in the notion of an unconditioned which precedes both system-parts and to which we return once it has been seen how they conjoin.

If this is how things stand in 1800, then it is not hard to understand how Schelling could, within a year, recast his philosophical system in terms that give the appearance of a final dissociation from transcendentalism. The Identity Philosophy, or System of Identity, which Schelling presents in 1801 seems to switch sides from Kant to Spinoza. ${ }^{42}$ This impression of discontinuity, whatever its local strategic value in terms of making plain his

\footnotetext{
${ }^{40}$ A concept which Schelling does not repudiate in the manner of Fichte but regards as in need of re-analysis, to strip it of its unknowability: e.g., Ichschrift, 79-80 [I 173].

${ }^{41}$ Ichschrift, 76n [I 168-9n].

${ }^{42}$ Initially in the Darstellung meines Systems der Philosophie (1801).
} 
independence from Fichte, is however misleading. As we have just seen, STI intentionally leaves empty space. What very shortly thereafter leads Schelling to think that he can fill it - that he can articulate the unconditioned absolute in discursive wissenschaftlich terms - is his subsequent discovery of the concept of a point of absolute indifference between subjectivity and objectivity. This new conceptual figure allows the unoccupied space of STI to be reexpressed as the highest axiom of the System of Identity: if an absolute Indifferenzpunkt, in itself neither subjective nor objective yet sufficient for both, can be comprehended, then the system of philosophy does not need to be produced through a unification of opposites, rather its parts can be generated top-down from the whole. To that extent the Identity Philosophy is an extension of STI made possible by a conceptual innovation.

The developmental continuity becomes clear if we set STI alongside Schelling's 1804 System der gesammten Philosophie und der Naturphilosophie insbesondere ( $\mathrm{SgP})$, the most comprehensive articulation of his standpoint as it stood before the turn that leads to his 1809 Freiheitsschrift. At the beginning of $S g P$ Schelling rehearses the opening moves of $S T I$ with modifications that incorporate and show to advantage the new conceptual idiom of Identity Philosophy, while restoring the strong monistic claims of the Formschrift and Ichschrift: ${ }^{43}$ (1) Again we begin with the transcendental question of how knowledge is possible, and again Schelling tells us that reciprocal determination of subject and object holds the answer. (2) Reciprocal determination, Schelling notes, instantiates a single invariant form, that of subject-object identity, or judgemental affirmation (viz. of the terms of the identity relation, or of subject and predicate). (3) The manner in which Kant and Fichte refer this form exclusively to the subject, Schelling argues, is arbitrary: instantiation of the form is what constitutes the cognition, which is itself a fact, and necessarily conscious of itself as such; to qualify it as 'for me' or 'in relation to my mode of cognition' is to annul the cognition, not to rationalize it. (4) Since the form cannot be derived from either subject or object, it must be self-subsistent, and since it comprises affirmation, and produces identity, it must comprise self-affirmation and self-production. (5) The kind of being possessed by the form is accordingly that of God. The subjective

\footnotetext{
${ }^{43}$ System of Philosophy in General and of the Philosophy of Nature in Particular (1804) [extract], in Idealism and the Endgame of Theory: Three Essays, trans. Thomas Pfau
} (Albany, NY: SUNY, 1994), 141-50 [VI 137-51]. 
idealist model is thus inverted: 'Not I know, but only totality knows in me'; in absolute knowledge, 'it is not the subject as subject that knows, but reason'. ${ }^{4}$

\section{Schelling's substantive reinterpretation of the transcendental turn}

There are other texts from Schelling's first decade which bear on the question of his transcendentalism, and there is a great deal more relevant material to be extracted from STI and the Identity Philosophy writings, ${ }^{45}$ but enough has been said to make clear the complexity of Schelling's relation to transcendentalism played out in his texts from 1794 to 1804. Schelling begins in Kantianism, and each further phase of his development - which includes, in STI, a reconceptualization of transcendental method - can be represented as continuous with its predecessor. The Naturphilosophie, even though its primary motivation was not transcendental - and it held, as Schelling appreciated, the potential for being set in opposition to Kant's idealism - was eventually melded with transcendental philosophy in STI. The final result in 1804, after another set of innovations, appears however to equate Spinoza with Kant or perhaps even to subsume Kantian idealism within Spinozism. What are we to make of this? The vital points concerning Schelling's relation to transcendentalism, on my account, are the following.

1. Beyond justification. The de jure aim of transcendental philosophy is of relatively little interest to Schelling, for whom the transcendental question, 'how is cognition possible?', is not best understood as a question of justification or warrant; the justifiability of a cognition is, in his view, only one, subject-related property of it, necessarily subordinate to the original fact of cognition itself. For Schelling, the battle with skepticism has been fought and won: Kant's theory may lack systematicity, but nothing further needs to be done to make first-order cognition, at its own level, epistemically secure. ${ }^{46}$ Fichte's elaborations, to the extent that they are motivated by the intention of

\footnotetext{
${ }^{44} \mathrm{SgP}, 143,147$ [VI 140, 147].

45 To be mentioned in particular is Schelling's Philosophische Briefe über Dogmatismus und Kritizismus (1795), which provides an alternative approach to the whole topic of Schelling and transcendentalism, but requires independent treatment.

${ }^{46}$ Indicative of Schelling's stance are his remarks on 'absolute skepticism', STI, 7-8 [III 343-4].
} 
increasing the security of ordinary knowledge claims, make relatively little philosophical advance, and have the adverse effect of making the subjectivist character of transcendentalism more pronounced.

2. Anti-subjectivism. Ridding transcendental philosophy of its subjectivist bent disposing of the notion that philosophical reflection is conditioned by perspectivality - is instead the major task that presents itself to the transcendental philosopher in the wake of Fichte. Therein lies the value of Schelling's redesign of transcendental method in STI, which trades in turn on Schelling's claim to have fully rationalized Nature.

3. Freedom \& the practical. The other question lying within the orbit of transcendental philosophy, on Fichte's construal of it, and which co-determines Fichte's agenda from the Grundlage onwards, concerns the need to demonstrate the unity of theoretical and practical reason. This does not play the same leading role in Schelling, for an essentially simple reason. Schelling's works from 1794 to 1800 contain ample discussion of practical self-consciousness, and make extended use of the concept of practical postulation; and the problem of determining what human freedom consists in occupies him from the beginning to the end of his philosophical career. But the task which Fichte sets himself, viz. of demonstrating the mutual imbrication of theoretical selfconsciousness and consciousness of agency, is in Schelling's view approached from the wrong angle, for the reality of freedom has already been given alongside the unconditioned absolute. The problem is therefore not to establish freedom through the integration of our theoretical and practical powers, but to understand how aboriginal freedom filters down from the unconditioned absolute to individuated finite agents; Fichte has, in Schelling's perspective, taken up the problem from the wrong, Kantian end, seeking a fusion of Kant's system-components, without realizing that the answer lies in grasping our relation to the unity which originally makes those system-components possible. ${ }^{47}$

4. The transcendental question. Schelling's decade-long wrestling with the transcendental turn revolves, ultimately, around one single issue. To put the point in what is only a slightly exaggerated way, there is just one philosophical problem for Schelling, and it lies all the way upstream, and constitutes the point where, in his view, Kant and Spinoza are of one mind. The problem is not to find (identify, formulate) a single principle

${ }^{47}$ See STI, 3-4, 10-11 [III 332-3, 347]. In Part Four Schelling explains how theoretical and practical consciousness are at once interdependent and differentiated; see esp. STI, 156-9 [III 533-8]. 
- this is the work of a moment - but to understand what it means for there to be a single principle: to determine in what sense it is truly a principle, or has some other status, what it is to for us to grasp it, and what is revealed at the point where we do so. To describe this undertaking as aiming to determine the ultimate foundation of transcendental philosophy would continue to suggest that epistemic considerations are paramount, whereas what truly concerns Schelling is what comes into view once the epistemic task has been discharged. Completing the de jure project of transcendental philosophy may have been the original aim in Kant and Fichte's early Jena writings, but achieving it has led us to see that there is a deeper issue to be addressed.

It is when we try to specify this nebulous issue that the greatest difficulties are confronted, not just by his interpreters but by Schelling himself. Numerous different exegetical approaches and textual trails might be explored, but we can make a start by noting that Schelling has been seen to offer three different characterizations of the unconditioned absolute or, more accurately, of the region of systematic thought which he intends should correspond to it: (i) Absolute Ichheit as expressed in the principle A=A or I=I. (ii) The point of unification of transcendental and Naturphilosophie, ostended by their conjunction but not expressed as such on either side of the divide. (iii) Absolute identity knowing itself as Reason and as the pure indifference of subjectivity and objectivity.

Why these variations? Earlier we observed a difficulty faced by Schelling in the Formschrift, concerning the rendering of the absolute unconditioned as a principle, and if we now revisit that text, we can see how deep it goes. Consider the following passage, which comprises the crux of the Formschrift's argument:

[T] he ultimate axiom not only expresses the entire content and form of philosophy but also gives itself in this very fashion its own content and its own specific form simultaneously. (Inasmuch as it contains the content of all contents, it gives itself at the same time its own content; and insofar as it is determinate, and as such the form of all forms, it gives itself simultaneously its own form, inasmuch as it is an axiom as such. The material form induces the formal one.) [...] Thus that axiom furnishes [gibt] the general form of this connection, the form of the reciprocal determination of the content by the form, and of the form by the content. ${ }^{48}$

\footnotetext{
${ }^{48}$ Formschrift, 43 [I 94-5] (translation modified).
} 
What Schelling demands, therefore, is that the position occupied by the highest Grundsatz - of which, Schelling has plausibly argued, we may at least form a concept, for our systematic purposes - should be filled by the self-giving and self-formation of form as such. What follows directly from this is that the Grundsatz in question cannot be a proposition in the same sense as any other, or, alternatively put, that to the extent that we grasp it, our understanding of it must be quite unlike that of any other possible thought. The same must be said of the type of truth that it possesses: the highest Grundsatz itself cannot be true in the relatively plain sense in which it is subsidiarily true that content and form reciprocally determine one another, since what it aims to express ('give') is the form by virtue of which the form of reciprocal determination can obtain. ${ }^{49}$

In this light, it is an entirely reasonable question - which Fichte and Hegel make into an objection - why Schelling should have such confidence in his purported insight into the absolute unconditioned. A good part of the answer, I suggest, can be given under two headings, one relating to Kant and the other to Fichte.

(1) Schelling attaches inestimable importance to the concept of the intuitive intellect introduced by Kant in the Third Critique, as noted earlier. ${ }^{50}$ What should be emphasized is that, in Schelling's view, Kant has furnished a proof of the intuitive intellect, in virtue of having shown its necessity for the possibility of cognition in general, where cognition is to be understood, as noted above, not merely as a subjective item but as encompassing the reciprocal determination of the subjective and objective. Kant's own explication of the intuitive intellect in $\$ \S 76-77$, in Schelling's view, is incomplete: it is insufficient to say merely that no distinction of the actual from the possible obtains within it, that its cognition of objects is indistinguishable from its creation of them, that it achieves cognition of parts through delimitation of the whole, and so on; if these (essentially negative) determinations of the intuitive intellect are to make sense, then we cannot consistently forebear from corresponding positive characterizations. Thus it may be true that our own interest in illuminating our own cognition is what led us to form the concept of the intuitive intellect, but this is simply a fact concerning the order of philosophical discovery: if it is thinkable, as it must be, then it must also be considered

\footnotetext{
${ }^{49}$ That these come apart is, we saw, the crux of Schelling's system in STI. The Ichschrift proceeds with detours - e.g., Schelling's insistence that the principle in question is 'not at all objective', 66 [I 155] - but has the same upshot.
}

${ }^{50}$ See Ichschrift, 120n [I 232]. 
what it is for itself; in order for the concept to do the work that we need done, we are obligated to accord the intuitive intellect itself, the 'object' of the concept, its own reflexive reality.

(2) In just the way that Kant overshoots the mark in relation to his own selfcircumscribed purposes when he formulates the concept of the intuitive intellect, so too does Fichte when he postulates the absolute Ich at the outset of the Grundlage. Dispute surrounds its status, but the current consensus is that the first principle cannot be taken as a plain existential claim and that Fichte must in some way understand the absolute Ich as an Idea demanding realization. It is here that Schelling considers Fichte to have fallen short. His supposition is that, in this case if in no other, the interpolation of a gap between an Idea and its reality is nonsensical. Kant has of course shown that concepts in general do not, as such and of themselves, give proof of their own instantiation. But the present case is exceptional in the following radical respect: our relation to the concept of Ichheit is not that of merely entertaining a representation as a candidate for instantiation in, or subsumption of, an object; rather I discover myself to be already inside it - I discover it to be a condition of $m y$ being. Were this not so, I would be unable to form the relevant concept and to recognize in (my conception of) myself the attributes of absoluteness which, Fichte argues, define pure Ichheit. Thus, given that the concept of Ichheit is, as Fichte rightly maintains, that of a self-positing entity, it follows that necessarily there is self-positing, i.e., in Schelling's Spinozistic idiom, that there $i s$ a self-grounded and actually exercised power to be (absolute Selbstmacht). ${ }^{51}$ The conception of absolute Ichheit as merely an ideal which in regulative fashion sets practical reason a task of infinite approximation must therefore be rejected. In the first principle of the Grundlage, the ontological argument as it were finds its true home, and it is in these terms that Schelling employs Kant's concept of a practical postulate to designate the status of the highest Grundsatz. ${ }^{52}$

Supposing that Schelling has, in the ways just suggested or on other grounds, supplied as much of a proof of the unconditioned absolute as the post-Kantian context permits, the story is still not at an end, for there remains one outstanding question. Given

\footnotetext{
${ }^{51}$ See Formschrift, 45 [I 96], and Ichschrift, 84 [I 179].

${ }^{52}$ See my 'Kant's Practical Postulates and the Development of German Idealism', in German Idealism Today, ed. Markus Gabriel and Anders Moe Rasmussen (Berlin: Walter de Gruyter, 2017), 36-9.
} 
the reality-for-our-reason of the unconditioned absolute, can it thereby be concluded that all being is encompassed within and coincides with it? The question cannot be avoided, since, as we have seen, thought of the unconditioned absolute is not of the same order as thought with determinate content, and this leaves it open what ontological status attaches to the kind of reality that has been secured by Wissenschaft for the unconditioned absolute. In the $1804 \mathrm{SgP}$ Schelling is emphatic:

The form of the absolute affirmation of itself and by itself, which constitutes the very essence of the absolute is, I said, repeated in reason [...] the idea of God in the spiritual world is the first affirmation of all reality [Realität]; there is no other reality [...] By virtue of this affirmation [...] we recognize that nonbeing [Nichtseyn] is eternally impossible [...] and that ultimate question posed by the vertiginous intellect hovering at the abyss of infinitude: Why something rather than nothing? [warum ist nicht nichts, warum ist etwas überhaupt?], this question will be swept aside forever by the knowledge that being [Seyn] is necessary, i.e., by the absolute affirmation of being in knowledge [absolute Affirmation des Seyns in der Erkenntniß]. ${ }^{53}$

This is not Schelling's last word on the issue. It continues to occupy him, and in the Positive Philosophy that he begins to formulate in the 1820 s, he reverses his position. ${ }^{54}$ Whether Schelling's Spätphilosophie, in remaining orientated towards the same basic issue, can be described as transcendental, is a further matter, which cannot be pursued here.

If what I have been arguing is correct, Schelling's position is that commitment to the transcendental method delivers a substantive insight of a magnitude that directly reconfigures the philosophical landscape, conditioning the way in which we approach the topics which had been central for Kant and Fichte, and adding new questions to the agenda. It would not be strictly false to describe Schelling as modifying the transcendental method in a way that makes Fichte's departures from Kant, considerable as they are, appear

\footnotetext{
${ }^{53} \mathrm{SgP}, 152$ [VI 155] (translation modified). Schelling broaches the problem in STI, 32 [III 375-6].

${ }^{54}$ See my 'Thought's Indebtedness to Being: From Kant's Beweisgrund to Schelling's Quelle', in Schelling's Philosophy: Freedom, Nature, and Systematicity, ed. G. Anthony Bruno (Oxford: OUP, forthcoming).
} 
relatively conservative, but talk of a specifically transcendental method, once its application has come to be determined antecedently by the sort of substantial insight envisaged by Schelling, is liable to mislead: as I hope to have explained, Schelling does not consider the model of ideal-real reciprocal determination expounded in STI to be selfstanding. The alternative is to regard Schelling as dissolving away the mthodological selfcharacterization of the transcendental turn, by teasing out and elaborating the insight which is already present in Kant, silently undergirding what the first Critique presented as in essence a methodological revolution - an insight which, if Schelling is right, coincides with the affirmation of substance in Spinoza's Ethics. ${ }^{55}$

\section{References}

Beiser, Frederick. German Idealism. Cambridge MA: Harvard University Press, 2002.

Esposito, Joseph. Schelling's Idealism and Philosophy of Nature. Lewisburg: Bucknell, 1977.

Fichte, J. G. 'Concerning the Concept of the Wissenschaftslehre' (1794). In Early Philosophical Writings, trans. and ed. Daniel Breazeale, 94-135. Ithaca: Cornell University Press, 1988.

Gardner, Sebastian. 'German Idealism, Classical Pragmatism, and Kant's Third Critique'. In Pragmatism, Kant, and Transcendental Philosophy, ed. Gabriele Gava and Robert Stern. London: Routledge, 2016.

\footnotetext{
${ }^{55}$ Schelling's anti-methodologism begins in the Fifth of his Philosophische Briefe [I 3007].
}

I am indebted to the $B J H P$ referees for extremely helpful suggestions which have greatly improved this paper. 
Gardner, Sebastian. 'Kant's Practical Postulates and the Development of German Idealism', in German Idealism Today, ed. Markus Gabriel and Anders Moe Rasmussen, 27-71. Berlin: Walter de Gruyter, 2017.

Gardner, Sebastian. 'Thought's Indebtedness to Being: From Kant's Beweisgrund to Schelling's Quelle', in Schelling's Philosophy: Freedom, Nature, and Systematicity, ed. G. Anthony Bruno. Oxford: OUP, forthcoming.

Moore, A. W. The Evolution of Modern Metaphysics: Making Sense of Things. Cambridge: CUP, 2012.

Nassar, Dalia. The Romantic Absolute. Chicago: University of Chicago, 2014.

Rockmore, Tom, and Daniel Breazeale (eds). Fichte and Transcendental Philosophy. Basingstoke: Palgrave Macmillan, 2014.

Sacks, Mark. Objectivity and Insight. Oxford: OUP, 2003.

Sandkaulen-Bock, Birgit. Ausgang vom Unbedingten. Göttingen: Vandenhoeck \& Ruprecht, 1990.

Schelling, F. W. J. Sämmtliche Werke, ed. Karl Friedrich August Schelling, 14 vols. Stuttgart: Cotta, 1856-61.

Schelling, F. W. J. Aus Schellings Leben. In Briefen. Band 1: 1775-1803. Leipzig: Hirzel, 1870.

Schelling, F. W. J. The Unconditional in Human Knowledge: Four Early Essays 17941796, ed. Fritz Marti. Lewisburg: Bucknell University Press, 1980.

Schelling, F. W. J. System of Transcendental Idealism (1800), trans. Peter Heath. Charlottesville: University of Virginia, 1978. 
Schelling, F. W. J. Idealism and the Endgame of Theory: Three Essays, trans. Thomas Pfau. Albany, NY: SUNY, 1994.

Schutz, Walter. 'Das Problem der absoluten Reflexion'. In Vernunft und Freiheit, 6-38. Stuttgart: Reclam, 1981.

Vater, Michael, and David Wood (eds.). The Philosophical Rupture between Fichte and Schelling: Selected Texts and Correspondence (1800-1802). Albany, NY: SUNY, 2012. 